Marquette University

e-Publications@Marquette

$1-1-2015$

\title{
Troubles with Truth Commissions: Putting the Moral Aims of Truth Commissions to the Fore
}

Margaret Urban Walker

Marquette University, margaret.walker@marquette.edu

Published version. "Troubles with Truth Commissions: Putting the Moral Aims of Truth Commissions to the Fore," in The Performance of Memory as Transitional Justice. Eds S. Elizabeth Bird, Fraser M. Ottanelli. Portland, OR: Intersentia, 2015: 7-21. Publisher link. (C) 2015 Intersentia. Used with permission. 


\section{CHAPTER 1}

\section{TROUBLES WITH TRUTH \\ COMMISSIONS: PUTTING THE MORAL \\ AIMS OF TRUTH COMMISSIONS \\ TO THE FORE}

Margaret URBAN WALKER

'There would be such a thing as "the truth about the past" only if there were one most basic question about the past that was the concern of those inquiring into it, and there is no such question'.

Bernard Williams, Truth and Truthfulness ${ }^{1}$

The rapid proliferation of truth commissions has attracted intense and sustained attention. Depending on how one defines and counts them, there have been more than thirty and possibly more than forty such commissions in the past several decades. ${ }^{2}$ Attention by researchers, scholars, and participants tracking the rationales, operations, and outcomes of truth commissions escalated sharply in response to South Africa's innovative, controversial, and globally visible Truth and Reconciliation Commission in the mid-1990s. The scholarly attention to truth commissions has ranged from endorsement to scepticism. As early as 2001, in the introduction to the first edition of her landmark study of truth commissions, Priscilla Hayner says, 'Unfortunately, many comfortable assumptions have been restated over and over again in untested assertions by otherwise astute and careful writers, thinkers, and political leaders. ${ }^{3}$ High

1 B. Williams, Truth and Truthfulness: An Essay in Genealogy, Princcton: Princeton University Press, 2002, at 257.

2 For lists, see M. Freman, Truth Commissions and Procedural Fairness, New York: Cambridge University Press, 2006; G. Dancy, H. Kim, and E. Wiebelhaus-Brahm, 'The Turn to Truth: Trends in Truth Commission Experimentation', (2010) 9 Journal of Human Rights, at 45-64; T.D. Olsen, L.A. PAYNe, and A.G. ReITER, Transitional Justice in Balance: Comparing Processes, Weighing Efficacy, Washington, D.C.: United States Institutes of Peace, 2010; and P.B. HAYNER, Unspeakable Truths: Transitional Justice and the Challenge of Truth Commissions, New York: Routledge, second edition, 2011.

3 P.B. HAyner, Unspeakable Truths: Confronting State Terror and Atrocity, New York: Routledge, first edition, 2001, at 7. 
expectations and incautious generalisations, however, are increasingly being submitted to more careful scrutiny and methodologically rigorous attempts at empirical confirmation. ${ }^{4}$

Analysis of the roles, values, or effects of truth commissions is dauntingly complex. Claims about the aims of truth commissions encompass moral, civic, political, social, psychological, epistemological, and historical objectives. The varied aims of truth commissions can also focus on different levels and actors: the victims of political repression and violence, individual perpetrators, and the institutions and institutional cultures of a society that are implicated in abuses, as well as prevalent behaviours and self-understandings of social groups or socicty as a whole. Truth commissions have been said to do or aim at many things: to establish a clear and authoritative record of a period of abuses, including their causes, patterns, and circumstances; to restore the dignity and address the suffering of victims and their families; to prevent like abuses from recurring in the future; to create public accountability of individual perpetrators and societal institutions, and to examine complicity in a society at large; to make recommendations for reform, reparations, and prosecutions; to educate the public and to prevent denial and revisionism about eras of abuse; to create a new national narrative or a unifying collective memory; to promote democracy, the rule of law, and respect for human rights; to contribute to national reconciliation. ${ }^{5}$ Many of these objectives concern hoped-for outcomes (such as

While not uncritical, some early accounts entertained far-reaching psychological, social, and political effects of truth commissions. See M. Minow, Between Vengeance and Forgiveness, Boston: Beacon Press, 1998; R. Tertel, Transitional Justice, New York: Oxford University Press, 2000; R.1. Rotberg and D. Thompson (eds.), Truth v. Justice: The Morality of Truth Commissions, Princeton, Princeton University Press, 2000; and T.G. PHelPs, Shattered Voices: Language, Violence, and the Work of Truth Commissions, Philadelphia: University of Pennsylvania Press, 2004. Recent work is more consistently critical or even skeptical about the purposes and impacts of truth commissions. See T. Kelsall, "Truth, Lies, Ritual: Preliminary Reflections on the Truth and Reconciliation Commission in Sierra Leone', (2005) 27 Human Rights Quarterly, at 361-391; R. SHAw, 'Rethinking Truth and Reconciliation Commissions: Lessons from Sierra Leone', (2005) 130 United States Institute of Peace Special Report, www.usip.org/publications/rethinking-truth-and-reconciliation-commissions-lessonssierra-leone, accessed 27 March 2014; B.A. LEEBAw, 'The Irreconcilable Goals of Transitional Justice', (2008) 30 Human Rights Quarterly, at 95-118; DALY, 'Truth Skepticism: An Inquiry into the Value of Truth in Times of Transition', (2008) 2 The International Journal of Transitional Justice, at 23-41; B. HAMBER, Transforming Societies after Political Violence: Truth, Reconciliation, and Mental Health, Dordrecht: Springer, 2009; E. WiebelhausBrahm, Truth Commissions and Transitional Societies, New York: Routledge, 2010; T.D. Olsen, L.A. PAyne, and A.G. ReIter, Transitional Justice in Balance: Comparing Processes, Weighing Efficacy, Washington, D.C.: United States Institute of Peace Press, 2010; O.N.T. Thoms, J. Ron, and R. PARIS, 'State-Level Effects of Transitional Justice: What Do We Know?', (2010) 4 The International Journal of Transitional Justice, at 329-354.

These claims are repeated widely in what is now a large and multidisciplinary literature, including truth commission mandates and reports. A very short list of works that discuss truth commission aims and uses includes: J.E. MÉnDEZ, 'Accountability for Past Abuses', (1997) 19 Human Rights Quarterly, at 255-82; Minow, supra note 4; TEITEL, supra note 4; P.B. Hayner, Unspeakable Truths: Transitional Justice and the Challenge of Truth Commissions, 
healing for victims or prevention of human rights abuses) that can be described and possibly measured in the wake of a truth commission's operation. ${ }^{6}$

Telling the truth, within the scope of its mandate, about abuses in an era of repression or conflict is the least contestable aim of a truth commission. In this chapter, I focus on questions and criticisms concerning specifically 'the truth of the truth commission'. Part of my goal is to identify some distinct kinds of questions about the truth that a truth commission should try to tell. Looking at some actual and prominent critiques, I distinguish several distinct kinds of concerns: concern with lack of methodological rigor in truth finding; concern with decisions and practices of truth finding that produce problematic silences; and pursuing the 'wrong' truth, one that fails to meet the real needs of a society in transition or impedes the realisation of what those needs are.

More important, however, is what I hope these distinctions help to reveal: that there is a difference between a set of technical, methodological, organisational, and practical questions about how best to pursue and establish certain kinds of truths and a set of moral and political questions about which truths and whose truths it is important for a truth commission to tell. Both of these kinds of questions are fundamental to the work of truth commissions, but they are radically different kinds of questions. A truth commission is limited by its task-orientation, timing, organisation, expertise and resources, which pose difficult practical and technical questions about how to accomplish its work effectively. But it is the highly contestable moral and political questions about which truth it is urgent to find or acknowledge that alone can set the goal to which the practical questions are directed and to which they remain

New York: Routledge, second edition, 2011; B. HAMBER and R.A. WiLSON, 'Symbolic closure through memory, reparation and revenge in post-conflict societies', (2002) 1 Journal of Human Rights, at 35-53; T.A. BORER (ed.), Telling the Truths: Truth Telling and Peace Building in Post-Conflict Societies, Notre Dame, Ind.: University of Notre Dame Press, 2006. See also United Nations High Commissioner of Human Rights, Rule-of-Law Tools for Post-Conflict States: Truth Commissions, New York and Geneva: United Nations, 2006, available at www.ohchr.org/Documents/Publications/RuleoflawTruthCommissionsen.pdf, accessed 27 March 2014. The United States Institutes of Peace provides a compendium of truth commission mandates and reports, at www-dev.usip.org/category/publications/truthcommission, accessed 27 March 2014.

In addition to the critiques discussed below in section 1, significant critiques of claimed truth commission outcomes, especially concerning outcomes for victims and securing democracy and human rights, are: D. MendelofF, 'Truth-Seeking, Truth-Telling, and Postconflict Peacebuilding: Curb the Enthusiasm?', (2004) 6 International Studies Review, at 355-380, and D. Mendeloff, 'Trauma and Vengeance: Assessing the Psychological and Emotional Effects of Post-Conflict Justice', (2009) 31 Human Rights Quarterly, at 592-623; DALY, supra note 4; HAMBer, supra note 4; WiebelHaUs-BRAhm, supra note 4; and OlSEN, et al., supra note 4. Multiple practical challenges and escalating demands on truth commissions are discussed by P. Degreiff, 'Report of the Special Rapporteur on the promotion of truth, justice, reparation and guarantees of non-recurrence', United Nations Human Rights Council, A/HRC/24/42, 28 August 2013. 
subordinate. The multiple and diverse limits of truth commissions suggest the need for extension, disaggregation, and proliferation of truth recovery practices.

\section{TRUTH SCEPTICISM(S)}

Scepticism about the truth that truth commissions do or can tell comes in many varieties. I do not address wholesale scepticism about the possibility of producing some significant reasonably well-warranted findings. I take seriously that there are many facts to be unearthed, individual experiences to be told, and wellwarranted generalisations and explanatory narratives to be constructed by a truth commission. Instead, I want to look at three concerns about the truth that a truth commission might actually have told or that it undertakes to tell: concerns about undisciplined and incomplete truth; truth that creates silences; and telling the wrong truth.

Audrey Chapman and Patrick Ball offer an incisive assessment of the methodological and epistemological limitations that affect the ability of a truth commission to provide 'an official authoritative account of a contested past [...] in an objective and careful manner consistent with strict standards of historical and social scientific research'. ${ }^{7}$ Drawing on a study of commissions in Haiti, South Africa, and Guatemala, Chapman and Ball are most concerned that a focus on the 'micro-truth' of individual cases, collected unsystematically through victim or survivor statements and testimonies that are prone to subjective limitations and distortions of memory, cannot furnish the 'comprehensive' sort of truth that commissions are charged to discover. This truth is the 'macro-truth' about 'the magnitude of the violence, the patterns, the trends, and the locations in which it took place', as well as ideological and organisational factors. ${ }^{8}$ They are entirely aware that truth commissions are meant to serve many ends that compete for attention, and to find many kinds of truth that will not be equally accessible under constraints of time, resources, political will, cooperation, and evidence, as well as choices of operation and design. In response to this, they propose that truth commissions should dedicate themselves to the large scale macro-truth of contexts, causes, and patterns of violation rather than the micro-truth of particular events, cases, and people. ${ }^{9}$ This clarified focus will dedicate resources to a disciplined social scientific

7 A.R. CHAPMAN and P. BALl, 'The Truth of Truth Commissions: Comparative Lessons from Haiti, South Africa, and Guatemala', (2001) 23 Human Rights Quarterly, 1-43, at 4. See also in this vein the outstanding collection on South Africa's TRC, A.R. CHAPMAN and H. VAN DER Merwe (eds.), Truth and Reconciliation in South Africa: Did the TRC Deliver?, Philadelphia: University of Pennsylvania Press, 2008.

8 ChAPMAN and BALL, supra note 7, at 7.

9 ChAPMAN and BALL, supra note 7, at 41 . 
approach that seeks, and has a better chance of finding, broad explanations through 'verifiable scientific best practices. ${ }^{10}$

Chapman's and Ball's critique, taken as an analysis of how different choices, procedures, and methods of truth finding produce or preclude certain kinds of truth, is acute and invaluable. To the extent that a truth commission's job is to produce that big, data-intensive, and methodologically regimented picture, they are right to point out that much of what truth commissions do is either not directed to that end, or does not serve it well. Taken, however, as a guide for the correct operation of a truth commission, the analysis is more problematic: is a truth commission best understood as a process of regimented social science research? Should a scientifically controlled research project become the controlling truth commission function? Their own final recommendations, in fact, curiously fail to integrate two disparate objectives. They propose that the findings of a commission must be 'unequivocal, massive, objective, and undeniable, and made according to scientific best practices,' and (in the next sentence) that 'the findings should be victim-centred, telling the story from their point of view and validating their experiences.'11

Their argument, however, is entirely on the side of the first objective, consistently criticising precisely the forms of attention and participation that have made truth commissions victim-centred and validating (to the extent that they are). These include non-adversarial interviews and (increasingly, for a minority of victims) testimonies, and attention to the details of particular cases that respectfully witnesses the abuses of particular people and the suffering of particular survivors, rendering structural contexts and statistical patterns vivid and concrete as human stories with profound human costs. They offer an opportunity or even an imperative for societies to look directly at specific acts of brutality and oppression whose legacies they carry and an opportunity for victims to seek both acknowledgement and redress. ${ }^{12}$ Chapman and Ball find this orientation to the details of individual cases 'legalistic' in its emphasis on discrete violations of human rights norms and its use of individual cases as illustrations or examples. But this facet, which is the human face of the truth commission, expresses its moral purpose and its society's political commitments. A society in transition both needs and is owed an objective and impartial finding of facts about the causes, circumstances, and patterns of its history of violence and repression, and victims as members of society share in the value and meaning of such a public and historical reckoning. ${ }^{13}$ But if a truth commission

\footnotetext{
10 Chapman and Ball, supra note 7, at 42.

11 ChAPMAN and BALL, supra note 7, at 42.

12 L.J. Laplante and K. Theidon, 'Truth with Consequences: Justice and Reparations in PostTruth Commission Peru', (2007) 29 Human Rights Quarterly, at 228-250, stress the expectations of reciprocity, especially reparations, that motivate many victims to testify. includes as well the collective right of societies to know their histories of oppression. See
} 
does not hear, record, acknowledge, and address victims, and thus exhibit the concrete meaning of human rights standards and the human costs of their violation in a publicly visible space, a truth commission becomes a research project, controlled by a professional staff that ensures 'qualitative and quantitative rigor.' ${ }^{14}$ The victim-centred, validating, and dignifying functions (which Chapman and Ball themselves call 'perhaps the central premise on which trutl commission are founded'), as well as the crucial public civil pedagogy of human rights and political wrongs, which have played a role in defining the institution of the truth commissions, do not have anywhere obvious to go. ${ }^{15}$ The question arises: how do we know which truth a truth commission is supposed to tell?

The question persists in a second kind of critique that targets the ways in which a truth commission, in setting its mandate and terms of reference and deciding on its emphasis and operations, effectively causes some truths, or some tellers, to be silenced or obscured. Insofar as truth commissions do incorporate, even feature, victim testimonies in their proceedings or reports, they will, in Laurie Beth Clark's description, 'favour certain kinds of stories (possibly the most horrific ones), certain kinds of simplifications of the story (so that listeners' loyalties are not diminished by ambiguities and complexities), and certain kinds of storytellers (those with effective and culturally specific acting skills as well as identity positions familiar to listeners)'. ${ }^{16}$ Such 'staging' of the truth is inevitable, although it can be either more deliberate or more unreflective. On the deliberate end, Chapman and Ball point out that the South Africa TRC's disproportionate display of white victims in its public hearings cohered with a strategy of showing that wrong was done 'on all sides'. ${ }^{17}$ Yet truth commission mandates inherently

United Nations, 'Study on the right to the truth: Report of the Office of the United Nations High Commissioner for Human Rights', United Nations Document E/CN.4/2006/91, 8 February 2006; and United Nations, 'Impunity: Report of the independent expert to update the Set of principles to combat impunity, Diane Orentlicher, Addendum, Updated Set of principles for the protection and promotion of human rights through action to combat impunity', United Nations Document E/CN.4/2005/102/Add. 1, 8 February 2005.

15 Chapman and Ball, supra note 7 , at 12 . On the human rights pedagogy of truth commissions, see M.U. WALKer, 'Nunca Más: Truth Commissions, Prevention, and Human Rights Culture', in L. MAy and E. Eden berg (eds.), Jus Post Bellum and Transitional Justice, New York: Cambridge University Press, 2013.

L.B. Clark, 'Performing Truth', in K. Bilbija, J.E. Fair, C.E. Milton, and L.A. Payne (eds.), The Art of Truth-Telling About Authoritarian Rule, Madison: University of Wisconsin Press, 2005 , at $84-85$.

Chapman and Ball, supra note 7, at 39-40. See also A.R. Chapman and P. Ball, 'Levels of Truth: Macro-Truth and the TRC', in Chapman and van DER Merwe (eds.), Truth and Reconciliation in South Africa: Did the TRC Deliver?, at 143-168. James Gibson's large study of TRC effects, however, sees the identification of abuses on all sides as making a positive contribution to reconciliation in the South African case, in J.L. Gibson, Overcoming Apartheid: Can Truth Reconcile a Divided Nation?, New York: Russell Sage Foundation, 2004, at $75-77$ and at $335-338$. 
set the terms for which acts will be investigated and which victims of violence (and rarely, as in the South African case, which perpetrators of abuses) can be heard, whether they ponder all of the consequences of exclusion. Beyond a truth commission's terms of reference, exclusion or self-selection may be determined de facto by the nature of the truth recovery process and the situations of victims.

Priscilla Hayner discusses persisting problems of hearing women's stories in truth commissions, whether this involves under-reporting of violations against women, cultural suppression of women's speech, material obstacles (of finances, responsibilities, or mobility) to participation, or impediments to putting sexual violence on the agenda of truth commissions as a central instance of human rights abuse. ${ }^{18}$ Despite efforts at 'gender-sensitive' truth commission design, staffing, and operations, problems of exclusion and misrepresentation of women may persist. Kimberly Theidon, in her studies of truth recovery and reconciliation in Peru, claims that stigma, shame, pressure from men, and local policing of what a community should talk about diminished reporting of sexual violence (despite appropriately broad definitions and successful outreach). ${ }^{19}$ Yet when victim categories are known to be of special interest to a truth commission and suggest potential avenues of redress, there are incentives within communities to exhibit the kinds of victimisation in question, including sexual violence. ${ }^{20}$ Julie Guillerot points to the Peruvian truth commission's serious documentation of sexual violence and its role in making sexual violence visible, but provides detailed analysis of how the report's recommendations 'failed to reflect the complexity of the crimes and secondary damages suffered by women and girls during the conflict.'21 A complex and dynamic interaction of truth commission terms and procedures, community hierarchies of power, deep background gender inequalities, and individual calculations determines who speaks and what a commission is likely to hear and emphasise.

Gender is but one dimension of potential exclusion in projects of truth recovery. The cultural acceptability of confessional or confrontational truth telling and its timing should constrain how truth recovery is understood and

18 HAYNER, supra note 2, 85-90. See also International Center for Transitional Justice, written by V. Nesia H, Truth Commissions and Gender: Principles, Policies, and Procedures, New York: International Center for Transitional Justice, 2006.

19 K. Theidon, 'Gender in Transition: Common Sense, Women, and War', (2007) 6 Journal of Human Rights 453-478, at 457-.459. For broader discussion, see K. THEIDON, Intimate Enemies: Violence and Reconciliation in Peru, Philadelphia: University of Pennsylvania Press, 2013.

20 THEIDON, supra note 19 , at 462.

21 J. Guillerot, 'Linking Gender and Reparations in Peru: A Failed Opportunity', in R. RubioMARín (ed.), What Happened To The Women?: Gender and Reparations for Human Rights Violations, New York: Social Science Research Council, 2006, at 150-154. See 140-145 on the coverage of sexual violence; Guillerot cites the Final Report of the Truth and Reconciliation Commission, Volume VI, Chapter 1, Section 1.5 on sexual violence and Volume VIII, Chapter 2 , Section 2.1 on its gendered impacts. 
when (even perhaps whether) it should occur. ${ }^{22}$ The nature of conflict and the persistence and centrality of post-conflict identities may either block or postpone any authoritative truth recovery, or favour local and bottom-up projects; several investigators have found this in the uneasy peace in Northern Ireland. ${ }^{23}$ The very categories of 'victim' and 'perpetrator' (made even more precise by the mandate to investigate a certain set of offenses) can flatten complexity, suggesting mutually exclusive and perhaps internally homogeneous categories, even as they obscure lines of authority, chains of command, and institutional structures and cultures that play central roles in the occurrence and legitimation of violence. ${ }^{24}$ Jelena Subotić argues that elevating individual accountability in transitional justice mechanisms (including trials and truth commissions) deflects attention from state responsibility and widespread societal complicity or denial (and its roots in shared norms, beliefs, and practices); without these, large scale and systematic violence and repression either might not or could not occur. ${ }^{25}$

Victims who fall within the mandated categories to be heard by a truth commission may fail to or decline to participate for reasons ranging from objection to the 'victim' category itself, to a sense of futility in pursuing justice, to finding themselves unable to cope with their trauma, or to reconciling their own needs for healing or honouring bonds with their dead on the political timeline of the transition. The psychologist Brandon Hamber writes movingly of the 'gap' between the pace of individual psychological processes and collective political ones, so that survivors' needs may not intersect with political imperatives to move along and move on. ${ }^{26}$ Truth commissions are inherently

Kelsall, supra note 4 and Shaw, supra note 4 explore this issue. J. Braithwaite, 'Partial truth and reconciliation in the longue durée', (2011) 6 Contemporary Social Science, at 129146, explores the uncoupling of truth and reconciliation, and the priority of local reconciliation to truth-telling, in several Pacific contexts.

23 See B. Hamber, 'Rights and Reasons: Challenges for Truth Recovery in South Africa and Northern Ireland', (2002-2003) 26 Fordham International Law Journal, at 1074-1094; B. Rolston, 'Dealing with the Past: Pro-State Paramilitaries, Truth and Transition in Northern Ireland', (2006) 28 Human Rights Quarterly, at 652-675; P. LUNDY and M. McGovern, 'Whose Justice? Rethinking Transitional Justice from the Bottom Up', (2008) 35 Journal of Law and Society, at 265-292.

See T.A. BORER, 'A Taxonomy of Victims and Perpetrators: Human Rights and Reconciliation in South Africa', (2003) 25 Human Rights Quarterly, at 1088-1116.

J. Suвотіс́, 'Expanding the scope of post-conflict justice: Individual, state and societal responsibility for mass atrocity', (2011) 48 Journal of Peace Research, at 157-169. See also N. Dimitrijević, 'Justice beyond Blame: Moral Justification of (The Idea of) a Truth Commission', (2006) 50 Journal of Conflict Resolution, at 368-382, on the transformation of political culture, at 377 , including a culture of silence, at 378-379. Dimitrijević, however, holds that a truth commission has to return a society to its former 'civilised values', not an assumption that will fit many, perhaps most, cases of mass atrocity and authoritarian repression. See also, N.V. Nwogu, 'When and Why It Started: Deconstructing VictimCentered Truth Commissions in the Context of Ethnicity-Based Conflict', (2010) 4 The International Journal of Transitional Justice, at 275-289.

B. Hamber, Transforming Societies after Political Violence: Truth, Reconciliation, and Mental Health, Dordrecht: Springer, 2009, at 70 and 89-93. 
transient, have a job to do, and operate at most for a few years; grief and extreme traumatisation (including the need and the ability to 'tell one's story') follow no schedule. The choices truth commissions make and the ones made for them by the terms of their mandate (set by executive order, national legislation, or brokered peace agreements) define a conceptual universe of offences and victims and construct a practical process of outreach, interviews, and hearings that will leave many opportunities to hear some of the truth, and many people who could tell it, behind.

These limitations of mandate, design, and process operate given an idea of what larger story needs to be told. There is also a question of what that larger story itself is. Explicit terms of reference in a commission's mandate place certain events, acts, or persons in or out of the line of inquiry. Chapman and Ball note that Guatemala's Commission on Historical Clarification defined the period for investigation as beginning with internal armed confrontation in 1962, not with a 1954 coup organised by the United States' CIA, thus implicating guerrilla activity as the beginning of the war. ${ }^{27}$ Chile's National Commission on Truth and Reconciliation (1990-1991), its first and internationally influential truth commission, allowed investigation only of crimes of deadly force, ultimately numbering several thousand. It required a second commission, the National Commission on Political Imprisonment and Torture (2003-2005) to recognise over 28,000 cases of political imprisonment, many involving torture. ${ }^{28}$ Mahmood Mamdani, an early and persistent critic of the scope and operation of South Africa's TRC, argues that the Commission chose to define terms of its mandate precisely in ways that 'rewrote' the story of apartheid, evading the examination of it as a political system, reducing the principal actors to political activists and state agents, individualising victims and winnowing them to those who were subject to a small schedule of abuses, extending impunity to most perpetrators of the system, and so failing to support precisely its own finding that apartheid was a crime against humanity. ${ }^{29}$ The truth of a truth commission is precisely a commissioned truth. There is no evading questions addressing on whose behalf and to what ends the truth should be commissioned.

\section{DIFFERENT KINDS OF QUESTIONS}

I have reviewed concerns about methodologically loose pursuits of the truth; questions, terms, or procedures that have the effect of putting some truths to the

Chapman and BALL, supra note 7, at 13.

On the two commissions, see HAYNER, supra note 2, at 47-49 and 60-62.

M. Mamdani, 'Amnesty or Impunity? A Preliminary Critique of the Report of the Truth and Reconciliation Commission of South Africa (TRC)', in M. Du Plessis and S. Peté (eds.), Repairing the Past? International Perspectives on Reparations for Gross Human Rights Abuses, Antwerp-Oxford: Intersentia, 2007. 
side or silencing some voices; and wholesale ways of defining the subject of investigation that arguably systematically misdirect truth finding efforts, using prominent examples of these critiques. I suggest that these concerns may be divided into practical or technical questions, on the one hand, and moral or political ones, on the other. But this distinction between the technical and the moral does not line up in a simple way with the criticisms canvassed.

Methodological criticisms (including staffing, organisation, and data management issues) fall mostly in the category of the technical, yet some choices about the collection and representation of information fall into the category of moral decisions, for example whom to interview and how to do it, when individuals with crucial information are not research subjects but are likely to include victims, relatives of victims, witnesses, and perpetrators. In their study of victim participation in Peru's truth commission, LaPlante and Theidon suggest that victims (whose testimony is essential to the core function of getting the truth and to a public pedagogy concerning the reality and nature of violence) rarely come to the truth commission out of a simple desire to be heard but come with expectations of satisfaction and reparation, a sense of 'implicit contract' that anticipates reciprocity in the form of some reparative response from the state. ${ }^{30}$ Brandon Hamber discusses the sense of disillusionment or betrayal for some victims of South Africa's TRC when they did not learn more about their own cases. ${ }^{31}$ One cannot object to the view that a truth commission should use, to the extent possible, effective means of investigation to get to the truth it must tell. But to urge a truth commission to largely limit its role to obtaining largescale objective truths through scientific methodology either implicitly embeds or merely bypasses moral and political judgements on what work it is important for a truth commission to do, and whose rights or needs must be served by this work. These are not matters for technical or expert determination.

Wholesale or broad-ranging criticism of the truth a truth commission is designed to (or decides to) tell is, on the other hand, squarely in the domain of the moral and political. Mamdani's critique, for example, argues that the greatest wrong for which South Africa needed to account was the crime against humanity that was the apartheid system and its massive means of implementation (forced removals, pass laws, forced labour, and illegal detention) and that the public pedagogy of human rights and responsibilities was misdirected into a narrowly drawn and falsely individualised focus. I do not mean to endorse Mamdani's analysis of the TRC, but to point to the clearly moral and political nature of his critique: he argues that the TRC failed the great majority of South Africa's

HAMBER, supra note 26, especially at 65-70 and at 147-150. See also D. BACKER, 'Watching a Bargain Unravel? A Panel Study of Victims' Attitudes about Transitional Justice in Cape 'Town, South Africa', (2010) 4 The International Journal of Transitional Justice, at 443-456.
} 
victims, drastically contained just demands for reparations, and promoted reconciliation defined for a political elite. ${ }^{32}$

Problems of omitting truths and silencing voices, on the other hand, can be either practical or moral. Some exclusions are practical limitations subject to practical fixes, such as outreach, public participation in design, framing of the commission's work, gender-sensitivity, and so forth. Other exclusions result from choices guided (rightly or wrongly) by how a truth commission's moral purpose and political impact is understood. A choice to individualise responsibility or to point to wrongs on all sides can be a deliberate choice motivated by the belief that a truth commission's work can in this way better promote peace or reconciliation in a post-conflict setting with polarised views and oppositional identities.

Sorting into practical-technical and moral-political questions is, I argue, important. Without slighting the complexities of adopting (or adapting) methods of research and analysis for a truth commission, given decisions about what truth must be told, these technical questions are subordinate to the decisions about which truth must be told, in whose service, and with what purposes. The latter are what I am calling the 'moral and political' questions. Furthermore, the practical and technical questions will often have relatively determinate answers (even if not unique ones) and a lot of scope for instrumental reasoning and prediction that can adjust means to desired ends. The moral and political questions, however, are inevitably going to be contestable, and not generally questions of effective means to ends, as the debate will turn on the fulfilment of competing moral and political values and obligations. These are in many cases questions about weighing and balancing values and obligations, rather than producing outcomes, and about appreciating the evaluative meanings that certain public processes embody or can come to carry, perhaps differently for different segments of the public for whom a truth commission operates.

Truth commissions are not just any kind of investigative venture. They have a moral and political agenda. They are a distinct kind of institution that has emerged for a transitional political context with some characteristic features; they are among the core measures believed to serve some demands associated with justice in that context; and they have proliferated rapidly, with relationships of influence through technical assistance and consultation, borrowing, and lessons learned. This does not mean that there is one precise and preordained format or canonical aim for a truth commission, but it does mean that what we have come to call a truth commission is keyed to the context of a post-conflict or post-repression political transition and is intimately entwined with a certain kind of moral project that is recurrent, pointed, and urgent in that situation. Truth commission mandates and reports, for example, invariably propose to 
affirm, restore, or honour the dignity of victims of violence, and to contribute to the prevention of abuses in the future through a clear documentation and condemnation of what transpired in the past. ${ }^{33}$ Reports or mandates also sometimes claim to combat impunity, contribute to accountability, rebut denial, or foster national reconciliation. Through various iterations internationally, moral and political objectives and aspirations such as these have become associated with truth commissions. Truth commissions, along with criminal accountability, administrative exclusions for perpetrators, and reparations and remembrance for victims, bear part of the weight and carry part of the meaning of justice in transition. ${ }^{34}$

Without suggesting that there is a formula that fits all cases or renders competing demands commensurable, I will refer to this characteristic constellation of concerns as the truth commission's gesture of 'moral reclamation and political legitimation. ${ }^{35}$ This is not a novel idea, and that is part of my point. This is what we have learned to expect from this distinctive transitional institution. It is only one gesture of moral and political transformation, but it has some distinctive work to do in telling some version of the larger story of what happened, why it was wrong, who was harmed, who is responsible, and how all this entails responsibilities for society. ${ }^{36}$ The challenge for any particular truth commission is how to conduct an inquiry that embodies an affirmation or reaffirmation of basic moral decency (usually captured in the ostensibly universal language and categories of human rights); that is responsive to victims whose suffering, dignity, and rights must be acknowledged and whose needs must be addressed; that offers its society an accounting, and some forms of accountability, institutional or individual; and that offers lessons of reform and prevention.

The difficult task that faces every truth commission is how to incorporate and prioritise these goals; those decisions will constrain which truth and whose

33 See the United States Institutes of Peace Publications for truth commission mandates and reports, at www-dev.usip.org/category/publications/truth-commission, accessed $27 \mathrm{March}$ 2014.

34 Pablo de Greiff argues that the weakness of each standard transitional measure requires their application in concert for them to carry the 'meaning of justice'. In P. DE GREIFF, 'Theorizing Transitional Justice', in M.S. Williams, R. NAGY, and J. Elster (eds.), Transitional Justice, Nomos LI, New York: New York University, 2012.

35 The term 'reclamation' is suggested by H.M. WEINSTEIN and E. STOVER, 'Introduction: conflict, justice and reclamation', in E. Stover and H.M. Weinstein (eds.), My Neighbor, My Enemy: Justice and Community in the Aftermath of Mass Atrocity, Cambridge: Cambridge University Press, 2004, at 14-15. José Zalaquett speaks of 'moral reconstruction' in N. RoHTArriazA, 'The Need for Moral Reconstruction in the Wake of Past Human Rights Violations: An Interview with José Zalaquett', in C. Hess and R. Post (eds.), Human Rights in Political Transitions: Gettysburg to Bosnia, New York: Zone Book, 1999. 
truth a commission will attempt to find and tell. These decisions will not achieve universal consent nor are they matters for unilateral expert determination (although what it is feasible to attempt and how to make it happen require many kinds of expert input). These decisions will be found either more or less reasonable and responsible by various publics, and the fact that truth commissions have often been described as 'victim-centred' (though they might or might not in fact conform to this ideal) suggests that the needs of victims do and must have an especially central role. How these decisions are taken, explained, and implemented in the context of the larger transitional process will determine how much and for whom they lend initial legitimacy to the new political order. There is not and cannot be a single kind of truth (micro or macro; individualised or collective; objective and causal or subjective and experiential) that can reasonably claim it is 'the' truth that a truth commission must tell. Yet truth commissions are invariably time-pressured, under-resourced, overmandated, and imperfectly staffed. They are also not unreasonably politically strategic; a successor or reconstituted regime may need to prioritise and harmonise some set of transitional measures in the short term in a way that is hoped (correctly or not) to promote legitimacy and stability. The concerns I have reviewed about inadequately disciplined findings, truths that silence, and telling the wrong story are serious ones. I have sorted through them to better understand them, not to set them aside. There are indeed too many truths and not enough truth commission capacity to go around. What might these concerns constructively suggest?

\section{TRUTH TAKES TIME}

Fletcher, Weinstein, and Rowen suggest that societies will in fact experience 'open-ended processes of reckoning' and that 'conceiving transitional justice as an ongoing process of transformation that may be initiated by a set of interventions rather than defined as these interventions may be more useful', ${ }^{37}$ This view might be applied to truth-telling. A truth commission that occurs in the transitional short term might be seen as initiating rather than constituting a society's reckoning with its multi-layered and contested truths. There are several implications. One is that the first job of a truth commission is public clarity about its moral and political objectives and honest expectation-setting about its operation and impact. A truth commission will need to inspire, and it will need extensive cooperation which it should not assume comes free. But it needs to set a limited and specific agenda and to avoid creating hopes it will not fulfil. This

37 L.E. Fletcher and H.M. Weinstein with J. Rowen, 'Context, Timing and the Dynamics of Transitional Justice: A Historical Perspective', (2009) 31 Human Rights Quarterly, 163-220, at 216-217. 
might be achieved to some extent by the coordinated operation of a truth commission's inquiry with other transitional measures, perhaps most especially with reparations. ${ }^{38}$ Beyond this, however, a truth commission (especially when it occurs early in a transitional process) might be explicitly positioned as an initiation, rather than a culmination, of a society's commitment to recover the truth about its troubled past.

A truth commission should acknowledge the need to continue the task that it, with all its limitations, only begins. This resolve could be expressed both in the truth commission's own mandate and work as well as in the way a truth commission might be positioned as one among other successive or continuing truth-recovery initiatives. A truth commission's task characteristically includes recommendations; among its central recommendations should be that truth recovery continue through varied projects and institutions. It could thus present itself explicitly as an opening instalment in a long-term process of working through gaps, silences, and currently unavailable information and testimonies that might be forthcoming later. It could set agendas for rigorous empirical projects, rich qualitative studies, professional historical inquiries, and forensic projects of exhumation and investigation that could use but go beyond the archive a commission amasses. It could invite or initiate local micro-projects of intracommunal story-telling and remembrance, and intercommunal dialogue and history-writing, as well as continuing public education through school curricula, public discourse, and commemoration. It might establish an openended process for receiving testimonies and documentation, adding them to an archive with both popular and professional access. John Braithwaite, based on studies of the 'Peacebuilding Compared' project, has suggested the policy of permanent truth commissions that 'keep their doors open as long as is needed', because of the time it takes victims and perpetrators to tell the truth; possibly, after 100 years, the truth commission would exist as a museum or repository of testimonies and other information. ${ }^{39}$ Whether or not this is a practically feasible idea, it envisages a deliberately open-ended and long-term process of uncovering and preserving truths that could have varied implementations. Limitations of truth commissions also suggest a disaggregation of truth recovery, with diverse formats and portals operating concurrently or successively at different levels, so

See P. DE GREIFF, 'Theorizing Transitional Justice', on the need for mutual reinforcement of transitional measures. OlsEN, et al., supra note 4, Appendix 4, tabulate the occurrence of transitional measures from 1970-2004. Although they list only monetary reparations programs, it is striking that reparations for victims involving material transfers are the least used measure, while amnesties for perpetrators are the most used. on Dispute Resolution, Ohio State University Program on Alternative Dispute Resolution, http://moritzlaw.osu.edu/programs/adr/schwartz/index.php. For the Peacebuilding Compared project, see http://regnet.anu.edu.au/peacebuilding-compared/home, both accessed 27 March 2014. 
that truth finding means can be finely adjusted to the kinds of truth pursued and needs served in pursuing it. ${ }^{40}$

A truth commission might either be seen as initiating a planned sequence or medley of truth finding and truth preserving processes, or simply as being one among diverse truth recovery initiatives that a society puts on its agenda both for and beyond the transition. In either case, a truth commission is unburdened from having to promise or to attempt too many truths of too many kinds. Braithwaite also challenges transitional justice orthodoxy that supposes a necessary connection and privileged sequence in which truth is a prior condition of reconciliation. Braithwaite's research on a number of Pacific cases suggests that local reconciliation in some cases can occur not only in spite of but also because of silences and lies, yet that reconciliation can in turn create conditions for truth to be spoken over the long term, locally or top-down. ${ }^{41}$ Nor is it likely that all the truth a society needs to hear and digest is a truth officially commissioned and told as an official story. Bottom-up, participatory modes of truth telling can have strengths complementary to top-down truth telling and might reveal and strengthen justice capacities that exist outside of or below the state. ${ }^{42}$ Whether truth telling should happen early on the transitional timeline or not needs careful consideration in context; but the idea that early truth telling is all the truth telling there will be or need be is unsuited to any context. Openendedness and disaggregation allow for the possibility not only of accumulation but of rectifications and clarifications of truth over the long haul.

\section{CONCLUSION}

There is no one most basic question about the past and there is no one institution or process that allows a society or community to capture all of its needed truths. A truth commission is a limited transitional institution that supplies one component of a moral and political intervention. This intervention should signal and propel a larger and longer project of finding, rethinking, and preserving a society's truth. If the early response to truth commissions was often celebration, and current responses often involve scepticism, a future agenda for societal truth recovery should be to think clearly and carefully both about but also beyond what a truth commission can do.

40 Subotić, supra note 25, and Rolston, supra note 23, are among those who suggest disaggregation of truth finding practices.

41 Braith WAITE, supra note 22, at 131-135, 137, and 145.

42 See Lundy and MCGovern, supra note 23, and K. McEvoy, 'Beyond Legalism: Towards a Thicker Understanding of Transitional Justice', (2007) 34 Journal of Law and Society, at 411440 . 